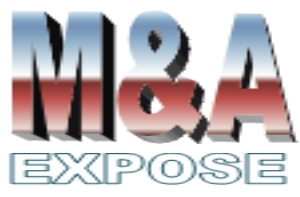

http://jurnal.usahid.ac.id/index .php/accounting
1,2Fakultas IImu Sosial dan Humaniora Universitas Bunda Mulia

${ }^{1}$ hyulita@bundamulia.ac.id 2bwiiaya@bundamulia.ac.id

\section{Pengaruh Kualitas Pelayanan Transportasi Publik terhadap Kepuasan Konsumen}

\author{
Henilia Yulita ${ }^{1}$, Brendi Wijaya ${ }^{2}$
}

\section{Abstrak}

Penelitian ini bertujuan menguji pengaruh kualitas pelayanan transportasi publik ( $P$-Transqual) terhadap kepuasan konsumen penumpang Kereta Api Commuter Line. Obyek penelitian adalah kualitas pelayanan yang terdiri dari personil, kenyamanan, bukti fisik dan keandalan sebagai variabel independen, serta kepuasan konsumen sebagai varibel dependen. Populasi penelitian ini adalah seluruh pengguna kereta api Commuter Line, dengan sampel sejumlah 389 responden. Teknis analisis yang digunakan adalah uji instrumen, uji prasyarat, dan uji hipotesis. Hasil penelitian menunjukkan bahwa terdapat pengaruh positif dan signifikan personil, kenyamanan, bukti fisik dan keandalan dari kualitas pelayanan terhadap kepuasan konsumen KRL Commuter Line secara parsial maupun simultan. Kesimpulannya kepuasan konsumen Kereta api Commuter Line sangat dipengaruhi oleh kualitas pelayanan transportasi publik ( $P$-Transqual). Diharapkan Pemerintah mengutamakan faktor kenyamanan sehingga para penumpang merasa aman ketika berada di Commuter Line dan petugas keamanan patut dipertahankan.

Kata kunci : personil, kenyamanan, bukti fisik, keandalan, kepuasan konsumen.

\section{Abstract}

This study aims to examine the effect of the quality of public transportation services (P-Transqual) on consumer satisfaction of Commuter Line Train passengers. The object of research is service quality consisting of personnel, comfort, tangible and reliability as independent variables, and customer satisfaction as the dependent variable. The study population was all Commuter Line train users, with a sample of 389 respondents. The technical analysis used is the instrument test, prerequisite test, and hypothesis testing. The results showed that there was a positive and significant influence of personnel, comfort, tangible and reliability of service quality on consumer satisfaction KRL Commuter Line partially or simultaneously. In conclusion, customer satisfaction on Commuter Line trains is strongly influenced by the quality of public transportation services (P-Transqual). It is hoped that the Government will prioritize the comfort factor so that passengers feel safe when they are on the Commuter Line and security officers should be maintained.

Keywords: personnel, comfort, tangible, reliability, customer satisfaction. 


\section{PENDAHULUAN}

Transportasi merupakan komponen penting dari sistem kehidupan kemasyarakatan dan pemerintahan. Di perkotaan, mobilitas masyarakat cenderung bergantung pada transportasi. Hal ini bertalian erat dengan jumlah penduduk perkotaan yang padat akibat tingginya natalitas dan urbanisasi. Fenomena yang timbul dari transportasi publik di Jakarta berkaitan dengan kenyamanan, keamanan dan keterjangkauan sangat mempengaruhi kualitas layanan (Bakti, 2015).

Wang (2010), Hussain (2015) dalam Chikazhe (2017) menyatakan bahwa kualitas layanan mengacu pada kesan keseluruhan dari penilaian yang dibuat oleh pelanggan mengenai layanan yang disediakan oleh perusahaan. Kualitas pelayanan dapat diketahui dengan cara membandingkan persepsi para konsumen atas pelayanan nyata yang mereka terima atau peroleh dengan pelayanan yang sesungguhnya mereka harapkan atau inginkan terhadap atribut-atribut pelayanan suatu perusahaan.

Kereta Rel Listrik (KRL) Commuter Line menjadi salah satu alat transportasi yang sangat diandalkan warga Jakarta, Bogor, Depok, Tangerang, dan Bekasi. Manfaat terbesar transportasi KRL Commuter Line adalah meretas kemacetan jalan, pengurangan polusi udara dan penghematan bahan bakar. Bagi warga perkotaan, selain alasan murah, KRL Commuter Line mampu memangkas waktu tempuh perjalanan bila dibandingkan dengan kendaraan bermotor bus, angkutan umum, mobil pribadi, atau motor.

Menurut Kepala BPS Suhariyanto, Badan Pusat Statistik (BPS) mencatat peningkatan jumlah penumpang kereta api secara signifikan dalam perkembangan pariwisata dan transportasi nasional tahun 2018. Jumlah penumpang kereta api tahun 2018 meningkat rata-rata sebanyak 36,8 juta orang atau 11,41 persen, di mana 79 persennya adalah penumpang Commuter Line (Putera, 2018).

Setiap hari antrian penumpang menumpuk super padat di tiap stasiun. Semua penumpang baik yang berbusana rapi dan perlente maupun yang berpakaian kasual, sekejap beringas begitu kereta tiba. Mereka siap bertempur demi mendapat satu tempat di gerbong kereta. Tubuh-tubuh penumpang saling sikut dan dorong. Sementara mereka yang telah lebih dulu berada dalam kereta harus siap bertahan (CNN_Indonesia, 2018).

Kejadian adu fisik sempat mewarnai kehidupan di gerbong wanita dan menjadi viral di media sosial. Keributan itu disebut-sebut akibat salah paham. Kedua perempuan saling menjambak rambut sambil duduk di atas bangku kereta khusus wanita. Penumpang lain di gerbong tersebut berusaha melerai keduanya. Namun dua perempuan itu tidak menghiraukan, hingga adu jambak berkepanjangan. Humas PT KAI Commuter Jabodetabek Eva Chairunisa mengimbau kepada pengguna jasa Commuter Line, khususnya penumpang wanita, agar menjaga ketertiban sehingga tidak mengganggu kenyamanan penumpang lain. Dalam kasus dua wanita jambak-jambakan tersebut, petugas memberikan sanksi kepada keduanya dengan diturunkan di stasiun terdekat (Liputan6, 2018).

Permasalahan yang berkaitan dengan transportasi publik tidak hanya diselesaikan secara teknis saja, melainkan menumbuhkan budaya dan kebiasaan masyarakat, baik dalam menggunakan transportasi publik maupun menciptakan kedisiplinan, kenyamanan, keamanan dan keteraturan dalam penggunaan transportasi publik. Contohnya mengenai kursi prioritas di Commuter Line yang berulang kali mencuat ke publik, tentu diperlukan hukum yang tegas dan sanksi yang memberatkan. Dengan demikian tidak hanya sekedar himbauan semata ataupun bersusah payah menerobos padatnya penumpang hanya untuk 
mencari petugas keamanan untuk meminta tempat duduk, melainkan mampu menciptakan tradisi kesadaran atas hak orang lain. Berdasarkan latar belakang yang diuraikan di atas, maka penelitian ini menganalisis pengaruh kualitas pelayanan transportasi publik $(P$ Transqual) terhadap kepuasan konsumen penumpang Kereta Api Commuter Line.

\section{TINJAUAN PUSTAKA}

Transportasi umum (dikenal pula sebagai transportasi publik atau transportasi massal) adalah layanan angkutan penumpang oleh sistem perjalanan kelompok yang tersedia untuk digunakan oleh masyarakat umum, biasanya dikelola sesuai jadwal, dioperasikan pada rute yang ditetapkan, dan dikenakan biaya untuk setiap perjalanan. (Schofer, 2018). Moda transportasi publik di antaranya bus kota, trem, kereta api, kereta cepat (metro/subway/bawah tanah), serta feri. Angkutan umum antar kota didominasi oleh maskapai penerbangan, bus antarkota, kereta api, dan kereta antarkota (McLeod, 2017).

Jaringan kereta berkecepatan tinggi sedang dikembangkan di banyak belahan dunia. Sebagian besar sistem transportasi umum berjalan di sepanjang rute tetap dengan titik pemberhentian dengan jadwal yang telah diatur sebelumnya. Taksi berbagi menawarkan layanan berdasarkan permintaan di banyak bagian dunia, dan beberapa layanan akan menunggu sampai kendaraan penuh sebelum taksi tersebut berangkat (McLeod, 2017).

Menurut Zeithaml (1988) dalam Bakti (2015) kualitas layanan mengacu pada penilaian pelanggan atas keunggulan keseluruhan atau keunggulan layanan perusahaan. Oleh karena itu, kualitas layanan transportasi darat publik mewakili evaluasi penumpang angkutan umum pada kinerja keseluruhan layanan transportasi umum. Semakin tinggi kinerja layanan angkutan umum, semakin positif persepsi penumpang pada kualitas layanan transportasi umum dan sebaliknya.

Namun, menurut Lovelock (2011) dalam Chikazhe (2017) kualitas pelayanan harus dimulai dari kebutuhan konsumen dan berakhir pada persepsi konsumen. Kualitas pelayanan dari suatu perusahaan tidak diukur dari sudut pandang pemberi pelayanan tetapi diukur dari sudut pandang penerima layanan. Keberhasilan dan kegagalan perusahaan bergantung pada bagaimana memberikan kualitas pelayanan yang baik serta meningkatkan niat beli konsumen.

Menurut Bakti (2015) terdapat empat dimensi pokok yang dikenal dengan istilah $P$ Transqual (public transportation quality) yang digunakan oleh pelanggan untuk menilai status kualitas pelayanan transportasi publik, yaitu sebagai berikut:

1. Bukti fisik (Tangibles) adalah kemampuan suatu perusahaan dalam menunjukkan eksistensinya kepada pihak eksternal. Penampilan dan kemampuan sarana dan prasarana fisik perusahaan yang dapat diandalkan serta keadaan lingkungan sekitarnya merupakan salah satu cara perusahaan jasa menyajikan kualitas layanan terhadap pelanggan. Faktor ini meliputi fasilitas fisik (gedung, buku, rak buku, meja dan kursi), teknologi (peralatan dan perlengkapan yang dipergunakan), serta penampilan pegawai.

2. Kenyamanan (Comfort) adalah kemampuan suatu perusahaan untuk menimbulkan perasaan aman dan nyaman bagi konsumennya ketika mengkonsumsi jasa pelayanannya.

3. Personil (Personnel) adalah suatu sikap keramahan, sikap hormat, dan empati yang ditunjukkan petugas yang memberikan jasa atau barang dalam melayani masyarakat. 
4. Keandalan (Reliability) adalah kemampuan perusahaan memberikan pelayanan sesuai dengan apa yang dijanjikan secara akurat dan terpercaya. Kinerja harus sesuai dengan harapan pelanggan yang tercermin dari ketepatan waktu, pelayanan yang sama untuk semua pelanggan tanpa kesalahan, sikap simpatik dan akurasi yang tinggi.

Terdapat beberapa peneliti yang mendukung perspektif ini adalah Andaleeb dan Basu (1994), Johns et al. (2004), dan Ramez (2012) dalam Bakti (2015). Literatur mengungkapkan bahwa skala pengukuran kualitas layanan menggunakan perspektif kinerja lebih unggul dibandingkan dengan skala pengukuran menggunakan perspektif diskonfirmasi. Menurut Caruana et al. (2000) dalam Bakti (2015), menggunakan skala perspektif diskonfirmasi membuat penilaian responden terhadap suatu item (misalnya pertanyaan tentang kinerja layanan) dapat dipengaruhi oleh penilaian responden atas item sebelumnya (yaitu pertanyaan tentang harapan layanan).

Kotler (2001) dalam Guy (2017) menandaskan bahwa kepuasan konsumen adalah tingkat perasaan seseorang setelah membandingkan kinerja (atau hasil) yang ia rasakan dibandingkan dengan harapannya. Bila kinerja melebihi harapan mereka akan merasa puas dan sebaliknya bila kinerja tidak sesuai harapan maka akan kecewa. Adapun menurut Sunyoto (2012) dalam Ratnasari (2016), kepuasan konsumen adalah tingkat perasaan seseorang setelah membandingkan (kinerja atau hasil) yang dirasakan dibandingkan dengan harapannya. Jadi tingkat kepuasan adalah fungsi dari perbedaan antara kinerja yang dirasakan dengan harapan. Konsumen bisa mengalami salah satu dari dua tingkat kepuasan umum yaitu kalau kinerja sesuai dengan harapan pelanggan akan merasa puas dan bila kinerja bisa melebihi harapan maka pelanggan akan merasakan sangat puas senang atau gembira.

Berdasarkan kajian pustaka dan temuan penelitian sebelumnya, maka dirumuskan hipotesis sebagai berikut :

H1. Terdapat pengaruh bukti fisik dari kualitas pelayanan terhadap kepuasan konsumen.

$\mathrm{H} 2$. Terdapat pengaruh kenyamanan dari kualitas pelayanan terhadap kepuasan konsumen.

H3. Terdapat pengaruh personil dari kualitas pelayanan terhadap kepuasan konsumen.

H4. Terdapat pengaruh keandalan dari kualitas pelayanan terhadap kepuasan konsumen.

H5. Terdapat pengaruh kualitas pelayanan secara simultan terhadap kepuasan konsumen.

\section{METODE PENELITIAN}

Jenis penelitian ini adalah penelitian kuantitatif. Penelitian kuantitatif adalah penelitian ilmiah yang sistematis terhadap bagian-bagian dan fenomena serta hubunganhubungannya. Tujuan penelitian kuantitatif adalah untuk mengembangkan dan menggunakan model sistematis, teori-teori dan/atau hipotesis yang berkaitan dengan fenomena alam (Liliwery, 2018).

Populasi penelitian ini adalah seluruh pengguna kereta api Commuter Line. Sampel penelitian ini menggunakan rumus Hair (2010) yaitu jumlah indikator dikali 10 yaitu 26 indikator $\times 10=260$ responden. Teknik pengambilan sampel yang digunakan dalam penelitian ini adalah purposive sampling. Teknik purposive sampling digunakan karena diperlukan dua kelas yang sama kemampuannya serta dapat mewakili karakteristik populasi. Jumlah sampel yang digunakan pada penelitian ini berjumlah 389 responden. 
Sugiyono (2012) menyatakan bahwa secara umum terdapat empat macam teknik pengumpulan data, yaitu observasi, wawancara, dokumentasi, dan triangulasi. Pada penelitian kali ini, peneliti menggunakan teknik triangulasi data yaitu dengan menggabungkan tiga teknik pengumpulan data (observasi, wawancara dan dokumentasi).

Berikut adalah variabel operasional menurut Bakti (2015) :
1. Personil :
a. Petugas Commuter Line mengenakan pakaian rapi.
b. Petugas Commuter Line cukup membantu.
c. Petugas Commuter Line cukup responsif.
d. Petugas Commuter Line memahami kebutuhan penumpang.
e. Petugas Commuter Line berlaku cukup sopan.

2. Kenyamanan :

a. Saya merasa aman dari kejahatan ketika berada di Commuter Line.

b. AC di Commuter Line membuat saya nyaman.

c. Saya merasa nyaman dengan sistem keamanan Commuter Line.

d. Perilaku penumpang lain di Commuter Line membuat saya nyaman.

e. Saya nyaman dengan kapasitas kursi Commuter Line yang cukup memadai.

3. Bukti fisik :

a. Kebersihan di dalam Commuter Line terjamin.

b. Kebersihan stasiun Commuter Line terjaga.

c. Kursi di Commuter Line dalam kondisi baik.

d. Mesin Commuter Line berada dalam kondisi baik.

4. Kehandalan: a. Kedatangan Commuter Line tepat waktu.

b. Waktu tempuh perjalanan Commuter Line cukup cepat.

c. Commuter Line berhenti sesuai rute.

d. Jumlah armada Commuter Line memadai.

5. Kepuasan konsumen: a. Saya sangat bergantung pada jasa transportasi Commuter Line setiap hari.

b. Saya akan selalu menggunakan jasa transportasi Commuter Line.

c. Saya akan merekomendasikan jasa transportasi Commuter Line ke orang lain.

d. Saya merasa puas dengan bantuan dari petugas Commuter Line

e. Saya merasa puas dengan keramahan petugas Commuter Line.

f. Saya merasa tenang sepanjang perjalanan.

g. Sistem jaringan Commuter Line jarang mengalami kendala

h. Saya merasa puas dengan kondisi fisik Commuter Line.

Teknik analisis data dalam penelitian ini adalah regresi linier berganda, yang diawali dengan uji instrumen, uji asumsi klasik, dan uji hipotesis. Uji instrumen dilakukan dengan memenuhi ketepatan dan kebenaran untuk melalui validitas dan reliabilitas. Uji asumsi klasik 
yang dilakukan sebelum uji hipotesis adalah uji normalitas, uji heterokedastisitas, uji multikolinieritas, dan uji koefisien korelasi. Uji hipotesis dengan melakukan uji t dan uji F.

Adapun uji validitas dan realibilitas masing-masing variabel adalah sebagai berikut :

Tabel 1. Validitas dan Reliabilitas Variabel Personil

\begin{tabular}{|c|c|c|c|}
\hline \multicolumn{4}{|c|}{ Item-Total Statistics } \\
\hline & $\begin{array}{c}\text { Corrected Item-Total } \\
\text { Correlation }\end{array}$ & R-tabel & Keterangan \\
\hline p1 & .621 & 0.113 & Valid \\
\hline p2 & .771 & 0.113 & Valid \\
\hline p3 & .803 & 0.113 & Valid \\
\hline $\mathrm{p} 4$ & .695 & 0.113 & Valid \\
\hline p5 & .644 & 0.113 & Valid \\
\hline
\end{tabular}

\begin{tabular}{cr}
\hline \multicolumn{2}{c}{ Reliability Statistics } \\
\hline Cronbach's Alpha N of Items \\
.875 & 5 \\
\hline
\end{tabular}

Sumber : Data diolah, 2019.

Data pada Tabel 1 menunjukkan bahwa bahwa semua peubah Personil memiliki nilai Corrected Item Total Corellation yang lebih besar daripada nilai $r$ tabel yaitu 0.113 sehingga semua peubah dinyatakan valid. Nilai Cronbahch's Alpha yaitu 0,875 lebih besar daripada 0,6 maka semua pernyataan tersebut dinyatakan reliabel.

Tabel 2. Validitas dan Reliabilitas Variabel Kenyaman

\begin{tabular}{|c|c|c|c|}
\hline \multicolumn{4}{|c|}{ Item-Total Statistics } \\
\hline & $\begin{array}{c}\text { Corrected Item-Total } \\
\text { Correlation }\end{array}$ & R-tabel & Keterangan \\
\hline p1 & .690 & 0.113 & Valid \\
\hline p2 & .641 & 0.113 & Valid \\
\hline p3 & .716 & 0.113 & Valid \\
\hline p4 & 672 & 0.113 & Valid \\
\hline p5 & .481 & 0.113 & Valid \\
\hline
\end{tabular}

\begin{tabular}{cr}
\hline \multicolumn{2}{c}{ Reliability Statistics } \\
\hline Cronbach's Alpha N of Items \\
.835 & 5 \\
\hline
\end{tabular}

Sumber : Data diolah, 2019.

Data pada Tabel 2 menunjukkan bahwa bahwa semua peubah Kenyamanan memiliki nilai Corrected Item Total Corellation yang lebih besar daripada nilai $r$ tabel yaitu 0.113 sehingga semua peubah dinyatakan valid. Nilai Cronbahch's Alpha yaitu 0,835 lebih besar daripada 0,6 maka semua pernyataan tersebut dinyatakan reliabel.

Tabel 3. Validitas dan Reliabilitas Variabel Bukti Fisik

\begin{tabular}{cccc}
\hline \multicolumn{4}{c}{ Item-Total Statistics } \\
\hline & $\begin{array}{c}\text { Corrected Item-Total } \\
\text { Correlation }\end{array}$ & R-tabel & Keterangan \\
\hline p1 & .696 & 0.113 & Valid \\
p2 & .617 & 0.113 & Valid \\
p3 & .696 & 0.113 & Valid \\
p4 & .601 & 0.113 & Valid \\
\hline
\end{tabular}

\begin{tabular}{rr}
\hline \multicolumn{2}{c}{ Reliability Statistics } \\
\hline Cronbach's Alpha & N of Items \\
.826 & \\
\hline
\end{tabular}

Sumber : Data diolah, 2019. 
Data pada Tabel 3 menunjukkan bahwa bahwa semua peubah Bukti Fisik memiliki nilai Corrected Item Total Corellation yang lebih besar daripada nilai $r$ tabel yaitu 0.113 sehingga semua peubah dinyatakan valid. Nilai Cronbahch's Alpha yaitu 0,826 lebih besar daripada 0,6 maka semua pernyataan tersebut dinyatakan reliabel.

Tabel 4. Validitas dan Reliabilitas Variabel Kehandalan

\begin{tabular}{cccc}
\hline \multicolumn{4}{c}{ Item-Total Statistics } \\
\hline & $\begin{array}{c}\text { Corrected Item-Total } \\
\text { Correlation }\end{array}$ & R-tabel & Keterangan \\
\hline p1 & .612 & 0.113 & Valid \\
p2 & .488 & 0.113 & Valid \\
p3 & .347 & 0.113 & Valid \\
p4 & .415 & 0.113 & Valid \\
\hline
\end{tabular}

\begin{tabular}{c}
\hline \multicolumn{2}{c}{ Reliability Statistics } \\
\hline Cronbach's Alpha N of Items \\
.680
\end{tabular}

Sumber : Data diolah, 2019.

Data pada Tabel 4 menunjukkan bahwa bahwa semua peubah Kehandalan memiliki nilai Corrected Item Total Corellation yang lebih besar daripada nilai $r$ tabel yaitu 0.113 sehingga semua peubah dinyatakan valid. Nilai Cronbahch's Alpha yaitu 0,680 lebih besar daripada 0,6 maka semua pernyataan tersebut dinyatakan reliabel.

Tabel 5. Validitas dan Reliabilitas Variabel Kepuasan Konsumen

\begin{tabular}{cccc}
\hline \multicolumn{4}{c}{ Item-Total Statistics } \\
\hline & $\begin{array}{c}\text { Corrected Item-Total } \\
\text { Correlation }\end{array}$ & R-tabel & Keterangan \\
\hline p1 & .439 & 0.113 & Valid \\
p2 & .614 & 0.113 & Valid \\
p3 & .668 & 0.113 & Valid \\
p4 & .685 & 0.113 & Valid \\
p5 & .589 & 0.113 & Valid \\
p6 & .635 & 0.113 & Valid \\
p7 & .426 & 0.113 & Valid \\
p8 & .451 & 0.113 & Valid \\
\hline
\end{tabular}

\begin{tabular}{rr}
\hline \multicolumn{2}{c}{ Reliability Statistics } \\
\hline Cronbach's Alpha & N of Items \\
.824 & 8 \\
\hline
\end{tabular}

Sumber : Data diolah, 2019.

Data pada Tabel 5 menunjukkan bahwa bahwa semua peubah Kepuasan Konsumen memiliki nilai Corrected Item Total Corellation yang lebih besar daripada nilai $r$ tabel yaitu 0.113 sehingga semua peubah dinyatakan valid. Nilai Cronbahch's Alpha yaitu 0,680 lebih besar daripada 0,6 maka semua pernyataan tersebut dinyatakan reliabel.

Selanjutnya hasil uji asumsi klasik adalah sebagai berikut : 


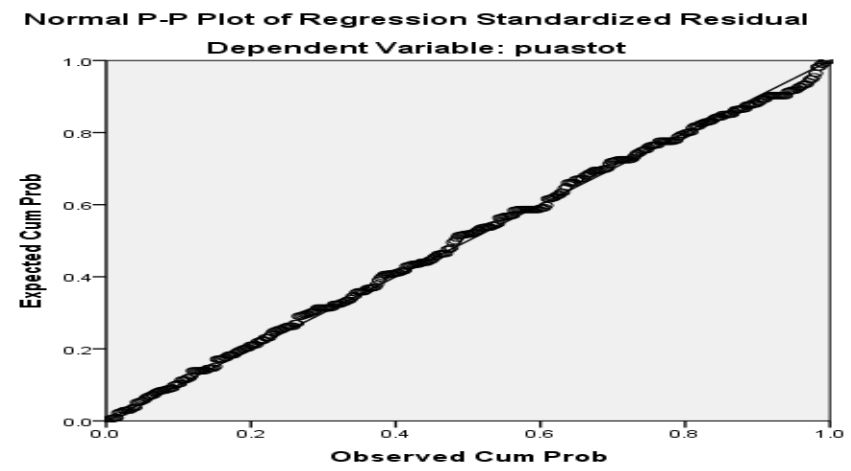

Gambar 1. Histogram Uji Normalitas

Hasil uji normalitas pada Gambar 1 menunjukkan bahwa data menyebar di sekitar garis diagonal dan mengikuti arah garis diagonal atau grafik histogramnya menunjukkan pola distribusi normal, maka model regresi memenuhi asumsi normalitas.

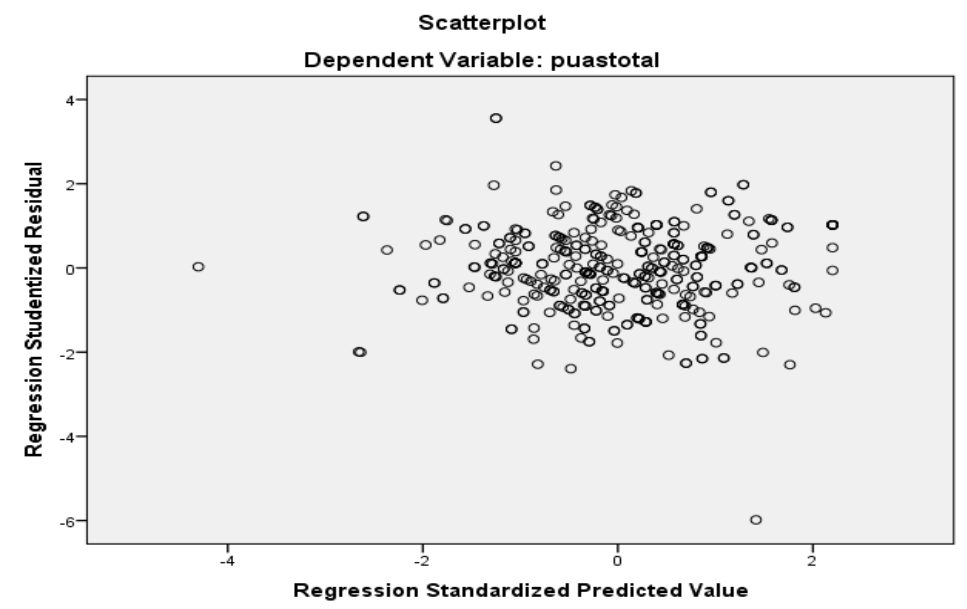

Gambar 2. Scatterplot Uji Heteroskedastisitas

Scatterplot pada Gambar 2 menunjukkan titik-titik menyebar di bawah serta di atas sumbu Y, dan tidak mempunyai pola yang teratur. Maka dapat disimpulkan peubah bebas di atas tidak terjadi heteroskedastisitas atau bersifat homoskedastisitas.

Tabel 6. Hasil Uji Multikolinieritas

\begin{tabular}{ccc}
\hline \multirow{2}{*}{ Model } & \multicolumn{2}{c}{ Collinearity Statistics } \\
\cline { 2 - 3 } & Tolerance & VIF \\
\hline Personil &, 565 & 1,771 \\
Kehandalan &, 470 & 2,130 \\
Kenyamanan &, 458 & 2,181 \\
Bukti Fisik &, 489 & 2,043 \\
\hline
\end{tabular}

Sumber : Data diolah, 2019.

Hasil uji multikolinieritas pada tabel 6 menunjukkan semua nilai tolerance lebih besar daripada 0,10 dan semua VIF lebih kecil daripada 10 , sehingga dapat dinyatakan tidak terjadi multikolinieritas pada model penelitian. 
HASIL DAN PEMBAHASAN
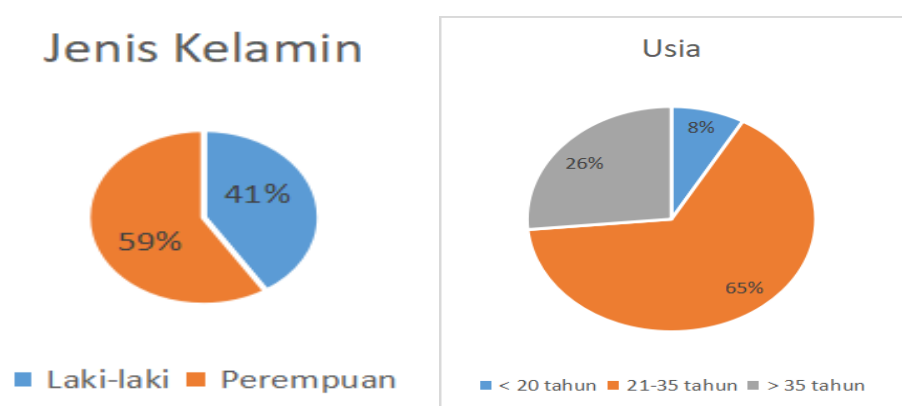

Pekerjaan

Gambar 3. Profil Pengguna Commuter Line

Sumber : Data diolah, 2019.

Gambar 3 menunjukkan bahwa profil pengguna Commuter Line adalah lebih banyak wanita, yaitu 59 persen; sedangkan pengguna laki-laki sebanyak 41 persen. Berdasarkan kategori usia, mayoritas pengguna Commuter Line adalah berusia sekitar 21 hingga 35 tahun. Adapun berdasarkan data pekerjaannya, pengguna terbanyak adalah karyawan, disusul pengguna terbanyak kedua adalah pelajar dan mahasiswa.
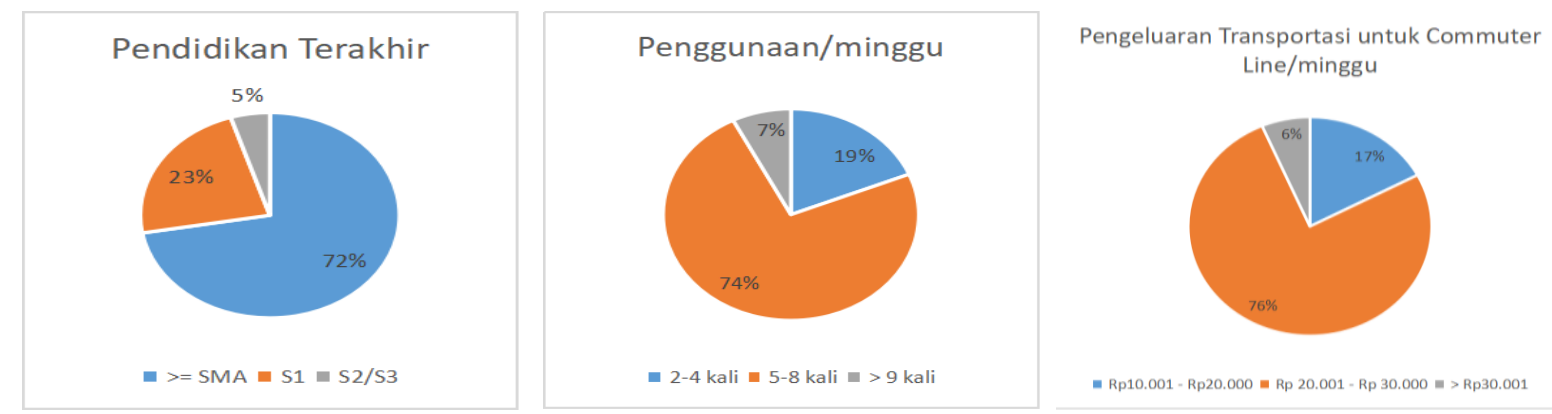

Gambar 4. Latar Belakang Pengguna Commuter Line

Sumber : Data diolah, 2019.

Gambar 4 menunjukkan bahwa 72 persen pendidikan terakhir pengguna adalah SMA. Adapun 74 persen pengguna menyatakan menaiki Commuter Line 5-8 kali setiap minggunya, hal ini menunjukkan bahwa sebagian besar pengguna menggunakan moda transportasi ini sebagai alat transportasi setiap hari. Pengeluaran transportasi sebagian besar pengguna setiap minggunya adalah Rp20.001-Rp30.000, hal ini menunjukkan bahwa pengguna mengunakan Commuter Line rutin setiap hari karena taripnya yang ekonomis.

Tabel 7. Koefisien Korelasi

\begin{tabular}{|c|c|c|c|c|}
\hline \multicolumn{5}{|c|}{ Model Summary } \\
\hline & & $\mathrm{R}$ & Adjusted R & Std. Error of the \\
\hline Model & $\mathrm{R}$ & Square & Square & Estimate \\
\hline 1 & $.724^{a}$ & .524 & .519 & 3.733 \\
\hline Predi & s: (Co & nstant), 1 & handal, persc & nil, bukti, nyaman \\
\hline
\end{tabular}


Tabel 7 menunjukkan bahwa variabel bukti fisik, kenyamanan, personil dan keandalan menentukan variasi perubahan kepuasan konsumen sebesar 52,4 persen. Adapun 47,6 persen lainnya ditentukan oleh variabel-variabel lainnya di luar model penelitian ini.

Tabel 8. Uji t

Coefficients $^{\mathrm{a}}$

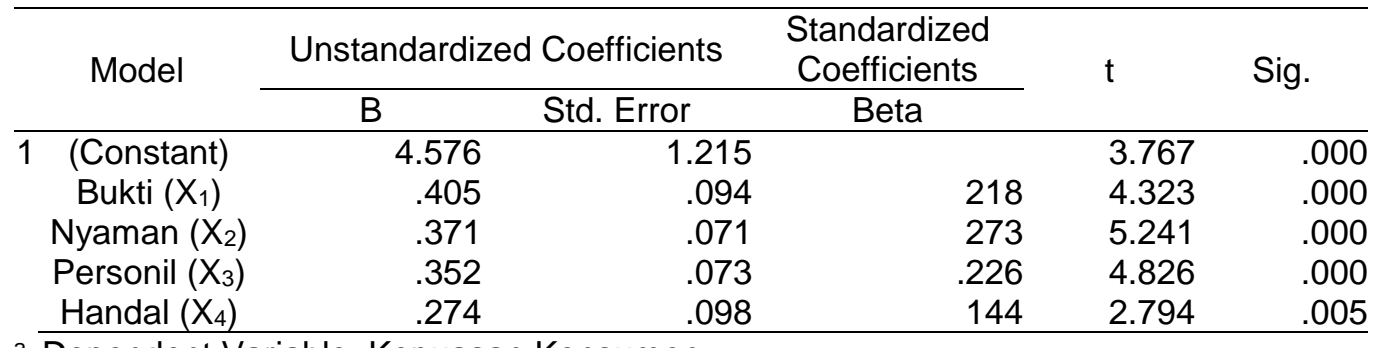

a. Dependent Variable: Kepuasan Konsumen

Sumber : Data diolah, 2019.

Berdasarkan Tabel 8 diketahui bahwa nilai t hitung untuk $X_{1}=4,323 ; X_{2}=5,241 ; X_{3}=$ 4,825; dan $\mathrm{X}_{4}=2,794$ signifikansinya lebih kecil daripada 0,05 . Dengan demikian dapat disimpulkan bahwa secara parsial terdapat pengaruh signifikan Bukti Fisik, Kenyamanan, Personil, dan Kehandalan terhadap Kepuasan Konsumen (Y).

\begin{tabular}{|c|c|c|c|c|c|c|}
\hline \multicolumn{7}{|c|}{ Tabel 9. Uji F } \\
\hline & Model & $\begin{array}{l}\text { Sum of } \\
\text { Squares }\end{array}$ & df & $\begin{array}{l}\text { Mean } \\
\text { Square }\end{array}$ & $\mathrm{F}$ & Sig. \\
\hline \multirow[t]{3}{*}{1} & Regression & 5879.968 & 4 & 1469.992 & 105.506 & $.000^{b}$ \\
\hline & Residual & 5350.181 & 384 & 13.933 & & \\
\hline & Total & 11230.149 & 388 & & & \\
\hline $\mathrm{De}$ & רdent Variak & : Kepuasan & nsumen & & & \\
\hline
\end{tabular}

Berdasarkan Tabel 9 diketahui bahw nilai F signifikansinya lebih kecil daripada 0,05. Dengan demikian dapat dinyatakan bahwa secara simultan terdapat pengaruh signifikan Bukti Fisik, Kenyamanan, Personil, dan Kehandalan terhadap Kepuasan Konsumen.

Tabel 10. Regresi Linier Berganda

Coefficients $^{\mathrm{a}}$

\begin{tabular}{|c|c|c|c|c|c|}
\hline \multirow{2}{*}{ Model } & \multicolumn{2}{|c|}{ Unstandardized Coefficients } & \multirow{2}{*}{$\begin{array}{c}\text { Standardized Coefficients } \\
\text { Beta }\end{array}$} & \multirow{2}{*}{$\mathrm{t}$} & \multirow{2}{*}{ Sig. } \\
\hline & B & Std. Error & & & \\
\hline (Constant) & 4.576 & 1.215 & & 3.767 & .000 \\
\hline bukti & .405 & .094 & 218 & 4.323 & .000 \\
\hline nyaman & .371 & .071 & 273 & 5.241 & .000 \\
\hline personil & .352 & .073 & .226 & 4.826 & .000 \\
\hline andal & .274 & .098 & 144 & 2.794 & .005 \\
\hline
\end{tabular}

Sumber : Data diolah, 2019. 
Berdasarkan Tabel 10 diketahui bahwa nilai signifikansi semua variabel lebih besar daripada 0,05 maka semua variabel $X$ (Bukti Fisik, Kenyamanan, Personil, dan Kehandalan) berpengaruh signifikan terhadap $Y$ (Kepuasan Konsumen). Persamaan regresinya adalah sebagai berikut :

$$
Y=4.576+0,405 X_{1}+0,371 X_{2}+0,352 X_{3}+0,274 X_{4}
$$

Koefisien regresi Bukti Fisik $\left(\mathrm{X}_{1}\right)$ sebesar 0,405 artinya apabila bukti fisik ditingkatkan, maka kepuasan pengguna Commuter Line akan meningkat. Koefisien regresi Kenyamanan $\left(\mathrm{X}_{2}\right)$ sebesar 0,371 artinya apabila kenyamanan ditingkatkan, maka kepuasan pengguna Commuter Line akan meningkat. Koefisien regresi Personil $\left(X_{3}\right)$ sebesar 0,352 artinya apabila faktor personil ditingkatkan, maka kepuasan pengguna Commuter Line akan meningkat. Koefisien regresi Kehandalan (X2) sebesar 0,274 artinya apabila kehandalan ditingkatkan, maka kepuasan pengguna Commuter Line akan meningkat.

\section{KESIMPULAN}

Berdasarkan analisis yang telah dilakukan, maka diambil kesimpulan bahwa:

1. Terdapat pengaruh bukti nyata dari kualitas pelayanan terhadap kepuasan konsumen $\mathrm{KRL}$ Commuter Line secara positif dan signifikan. Hal ini mendukung penelitian sebelumnya yang dilakukan oleh Bakti (2015).

2. Terdapat pengaruh kenyamanan dari kualitas pelayanan terhadap kepuasan konsumen $\mathrm{KRL}$ Commuter Line secara positif dan signifikan. Hal ini mendukung penelitian sebelumnya yang dilakukan oleh Bakti (2015).

3. Terdapat pengaruh personil dari kualitas pelayanan terhadap kepuasan konsumen KRL Commuter Line secara positif dan signifikan. Hal ini mendukung penelitian sebelumnya yang dilakukan oleh Bakti (2015).

4. Terdapat pengaruh reliabilitas dari kualitas pelayanan terhadap kepuasan konsumen $\mathrm{KRL}$ Commuter Line secara positif dan signifikan. Hal ini mendukung penelitian sebelumnya yang dilakukan oleh Bakti (2015).

5. Terdapat pengaruh positif dan signifikan antara seluruh faktor kualitas layanan secara simultan terhadap kepuasan konsumen $\mathrm{KRL}$ Commuter Line. Hal ini mendukung penelitian sebelumnya yang dilakukan oleh Bakti (2015).

Berdasarkan hasil penelitian, terdapat beberapa saran yang diharapkan dapat menjadi bahan pertimbangan untuk manajemen Commuter Line dan peneliti selanjutnya. Pihak manajemen Commuter Line hendaknya meningkatkan faktor kenyamanan seperti merasa aman dari kejahatan ketika berada di Commuter Line, AC (Air Conditioning) di Commuter Line yang cukup dingin, dan sistem keamanan Commuter Line dengan tersedianya petugas keamanan di hampir setiap gerbong karena terbukti berpengaruh paling dominan terhadap tingkat kepuasan konsumen Commuter Line. Penelitian selanjutnya disarankan menambahkan variabel-variabel selain P-Transqual, selain itu juga objek penelitian dapat diperluas untuk menguji moda transportasi publik lainnya seperti TJ (Trans Jakarta) atau MRT (Mass Rapid Transit) yang baru saja diluncurkan. 


\section{DAFTAR PUSTAKA}

Bakti, I. G. (2015). P-Transqual: a Service Quality Model Of Public Land Transport Services. International Journal of Quality \& Reliability Management, 32(6), p.534-558.

Chikazhe, M., Charles \& Lovemore. (2017). Mediator of The Relationship between Service Quality and Customer Loyalty: Evidence from The Banking Sector in Zimbabwe. International Journal of Bank Marketing, 35(3), p.540-556.

CNN_Indonesia. (2018, September 14 Retrieved from https://www.cnnindonesia.com/nasional/20160913202358-21-158046/keretakomuter-high-heels-dan-risiko-mati-cepat

Ervan H. (2018, Februari 26) Retrieved from https://internasional.kompas.com/read/2018/02/26/14444501/indeks-persepsikorupsi-2017-peringkat-indonesia-di-bawah-timor-leste

Guy P. (2017). Role of Social Media in Retail Network Operations and Marketing to Enhance Customer Satisfaction. International Journal of Operations \& Production Management, 37(1), p. 105-123.

Hair, J.F., Black, W.C., Babin, B.J., Anderson, R.E., \& Tatham, R. L. (2010). Multivariate Data Analysis, Seventh Edition. Pearson Prentice Hall.

Liliweri, P. A. (2018). Paradigma Penelitian IImu Sosial. Yogyakarta: Pustaka Pelajar.

Liputan6. (2017, Agustus 14). Retrieved from https://kabaru.id/news/hukum-rimba-di-krljakarta-7447: https://kabaru.id/news/hukum-rimba-di-krl-jakarta-7447

McLeod, S. (2017). Urban Public Transport: Planning Principles and Emerging Practice. Journal of Planning Literature, SAGE, p.223-239.

Mutia F. (2018, September 18). Retrieved from ekonomi.kompas.com: https://ekonomi.kompas.com/read/2018/09/18/071100326/bps--indeks-perilaku-antikorupsi-masyarakat-indonesia-alami-penurunan

Nailufar, N. N. (2017, Mei 16). Retrieved from http://jatim.tribunnews.com/: http://jatim.tribunnews.com/2017/05/16/rebutan-duduk-di-krl-dua-perempuan-jambakjambakan-netizen-emang-neraka-gerbong-cewek?page $=2$

Putera, A. D. (2018) Retrieved from www.ekonomi.kompas.com: https://ekonomi.kompas.com/read/2018/09/03/165231726/pengquna-krl-dongkrakumlah-penqquna-kereta-pada-aqustus-2018

Putri, P. K. (2017, Mei 17). Retrieved from https://news.detik.com: https://news.detik.com/berita/d-3503276/merasakan-ganas-nya-gerbong-wanitacommuter-

Ratnasari, A. (2016). Pengaruh Kualitas Pelayanan dan Harga terhadap Kepuasan Pelanggan (Studi Kasus pada Salon Cantik). Jurnal IImiah Prodi Manajemen Universitas Pamulang, 4(1).

Schofer, J. L. (2018). Mass Transportation. USA: Encyclopædia Britannica.

Sugiyono. (2012). Metode Penelitian Kuantitatif, Kualitatif, dan R\&D. Bandung : Alfabeta, CV.

Web Sindo. (2019, Maret 7). Retrieved from https://websindo.com/indonesia-digital-2019media-sosial/ 